UNDERGRADUATE RESEARCH IN NATURAL AND CLINICAL SCIENCE AND TECHNOLOGY (URNCST) JOURNAL Read more URNCST Journal articles and submit your own today at: https://www.urncst.com

\title{
Effects of the Inhalation of Fenvalerate Combustion Products on the Respiratory, Digestive, Endocrine, and Muscular Systems of Mice: A Research Protocol
}

\author{
Nicholas Laflamme, BASc Student [1]*, Jasmine Candeliere, BSc Student [2], \\ Rebecca Krnel, BSc Student [2], Darius E. Stamatakos [2] \\ [1] Faculty of Engineering, University of Ottawa, Ottawa, ON, Canada K1N 6N5 \\ [2] Faculty of Science, University of Ottawa, Ottawa, ON, Canada K1N 9B4 \\ *Corresponding Author: nlafl102@uottawa.ca
}

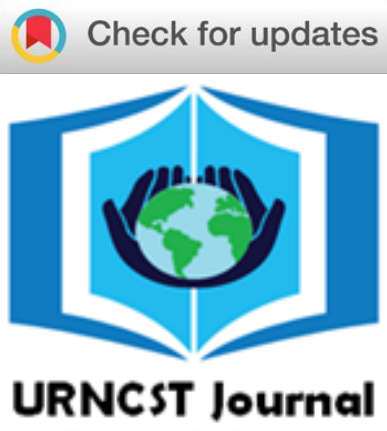

"Research in Earnest"

\begin{abstract}
Currently, very little scientific literature investigates the adverse health effects of pesticides found in cannabis. With the legalization of cannabis, regulation of pesticide usage must also be modified since these crops are not merely ingested, they are also smoked, creating new chemical compounds that are potentially harmful to the human body. That being said, research shows that the combustion of federally approved pesticides, such as fenvalerate, produces chemicals that are harmful when ingested, most notably hydrogen cyanide. This study will investigate the potential effects of the combustion products of fenvalerate when they are inhaled. By studying mice, we will investigate the potential effects of these products on their respiratory, digestive and muscular systems, as well as the potential effects on consumer health faced with long-term exposure to combustion by-products. Doing so will also enable the construction of a framework for determining adequate pesticides for industrial production of cannabis.
\end{abstract}

Keywords: cannabis; combustion; health; hydrogen cyanide (hen); pesticides; public chronic exposure; smoke inhalation; toxicology

\section{Introduction}

Cannabis sativa and Cannabis indica are the two plant species responsible for the production of the psychoactive drug known as cannabis, which is a drug that can be smoked, vaporized, or ingested [1]. Due to the recent legalization of cannabis for both medical and recreational use, its growth and production have been industrialized. With such largescale production, the use of pesticides on crops has been implemented [2]. The use of pesticides has been regulated on food products; however, there are different implications with cannabis.

Smoking has been reported as the main method of consumption by $94 \%$ of respondents of the 2017 Canadian Cannabis Survey [3], with most Canadians smoking on average 1.6 grams of cannabis per day for medical purposes, as well as 0.9 grams per day for recreational use $[4,5]$. This presents new health risks linked to the possibility of toxic byproducts created by the combustion of active ingredients found in pesticides. Furthermore, current findings show that some pesticides are highly volatile and become carcinogenic under pyrolytic conditions, such is often the case with cannabis consumption [6, 7]. In addition, as much as $69.5 \%$ of applied pesticide residues can be recovered from cannabis smoke [8].

Following the legalization, the Canadian Government released a list of limits for various active ingredients found in pest control products for the use of cannabis [2]. Of the list, certain ingredients have no set limits yet. Of these unregulated active ingredients is fenvalerate, which has been found to produce hydrogen cyanide $(\mathrm{HCN})$ when combusted [9]; a chemical compound that leads to the inhibition of cytochrome oxidase, preventing the use of oxygen by cells [10]. Repeated and chronic exposure to the gas can result in hypothyroidism, upper respiratory tract (URT) irritation, and potentially iodine deficiency disorders by ways of inhibition of sodium iodine symporters in the blood.

That being said, the effects of chronic exposure to $\mathrm{HCN}$ are not well documented [11, 12]. The combustion of this pesticide is particularly concerning due to its absorption efficiency by inhalation, possibly making smokers more vulnerable to its toxic effects [13]. Exposure from smoking cannabis can be understood by analyzing exposure from cigarette smoke, which also contains HCN. In fact, one breath of an unfiltered cigarette containing $35 \mu \mathrm{g}$ of $\mathrm{HCN}$ would expose the lungs to a concentration of $46 \mathrm{ppm}$, further increasing the risk of acute cyanide poisoning, as well as abnormalities of vitamin $\mathrm{B}_{12}$, folate and thyroid function, all indicative of long-term $\mathrm{HCN}$ exposure [14, 15].

Based on current literature, mice exposed to fenvalerate under pyrolytic conditions could present themselves with health conditions such as hypothyroidism or iodine deficiency syndromes, which are indicative of long-term $\mathrm{HCN}$ exposure. There is currently little literature that investigates the health effects regarding long-term exposure 


\section{UNDERGRADUATE RESEARCH IN NATURAL AND CLINICAL SCIENCE AND TECHNOLOGY (URNCST) JOURNAL}

Read more URNCST Journal articles and submit your own today at: https://www.urncst.com

to combustion by-products of pesticides. Further research will provide information about the health risks associated with chronic, long-term exposure to combustion by-products of fenvalerate, specifically $\mathrm{HCN}$. Once concentration thresholds for various insecticide fumes have been determined, such as fenvalerate, alternative and cleaner insecticide options could then be provided for the production of cannabis.

\section{Methods}

In order to reach justifiable conclusions, it is important to test the effects of fenvalerate on a species closely linked to humans. Thus, this study will include 120 healthy adult mice (each weighing $18 \mathrm{~g}$ to $20 \mathrm{~g}$ ) of the C57BL/6 strain, which is commonly used as a physiological model for in vivo experiments [16]. The mice will be kept in cages similar to (Figure 1) for the 12-week study.

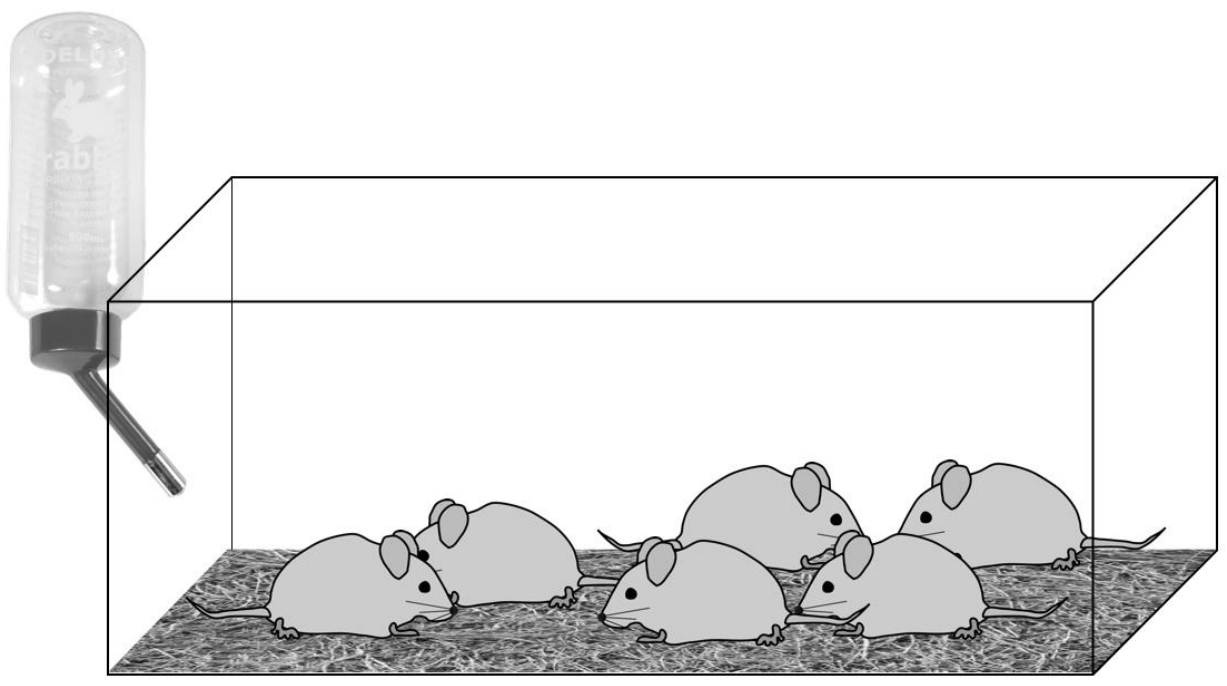

Figure 1: Mouse Cage Setup

They will be divided into 5 groups of 24 individuals, and each will receive unlimited water and be fed the same diet. The first control group will set our baseline on the expected health of the mice as they will not be exposed to the active ingredient. The second control group will be exposed to cannabis smoke without any pesticides and will serve to differentiate the sideeffects caused by fenvalerate and by general smoke inhalation.

The last three groups will inhale the combustion products of fenvalerate-contaminated cannabis at a concentration of 10,25 , or $50 \mathrm{ppm}$ twice daily for 20 minutes with a 60-minute interval in between exposures. The fan system will also provide $150 \mathrm{~mL}$ of fresh air every ten seconds. Fenvalerate will be continuously combusted in the smoke generating system to properly expose the mice to its combustion products. The smoke exposure system, as shown in (Figure 2), was inspired by Ypsilantis and colleagues in their 2012 study [17]. Non-contaminated apples will be fed to all groups.

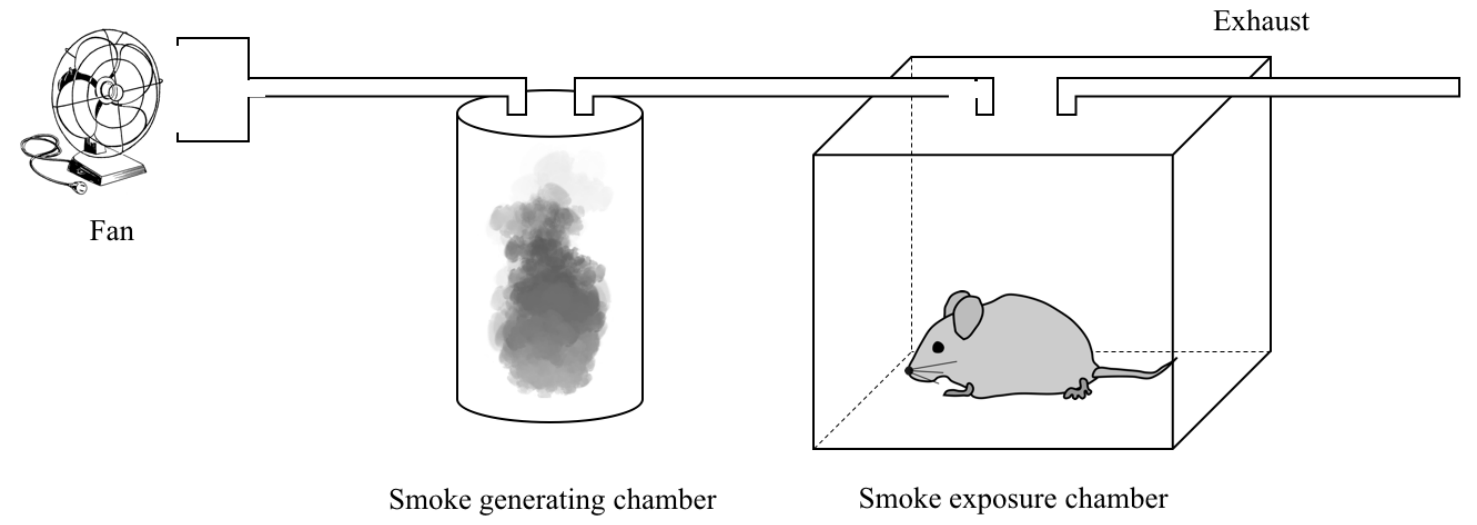

Figure 2: Smoke Exposure System 
UNDERGRADUATE RESEARCH IN NATURAL AND CLINICAL SCIENCE AND TECHNOLOGY (URNCST) JOURNAL Read more URNCST Journal articles and submit your own today at: https://www.urncst.com

A sample of urine, saliva, red blood cells and plasma will be collected every week from every mouse immediately after being exposed. The concentrations of cyanide, thiocyanate and fenvalerate will be analyzed in all the biofluids listed above [18]. It is important that we test the biofluids very quickly since the half-life of cyanide is only 1 hour [19].

Observations such as the mouse's lumps, masses, body condition, behaviour, and strength will be noted on a daily basis [20]. We will also monitor for the development of hypothyroidism with bi-weekly blood tests to determine levels of $\mathrm{T} 4$ [21]. The number of lumps and masses, as well as their size, will be noted every day for each mouse. The body condition is a qualitative observation based on the weight of the mouse. Their behaviour will be evaluated on how active they are in their cages during the experiment. Finally, their strength will be evaluated using Kondziela's inverted screen test [22].

At the end of the 12-week study, the mice from each group will be dissected and have their respiratory, digestive, and muscular systems evaluated. Each system will be examined for contamination and tumours.

\section{Statistical Analysis}

A table similar to Table 1 (shown below) will be filled out for each group during the 12 week study. To check the statistical significance of the different means obtained, a Kruskal-Wallis test and Dunn's test will be done on the means of each group.

Table 1: Average concentrations of cyanide (C), thiocyanate (TC) fenvalerate (F) and iodine (I) in the biofluids tested

\begin{tabular}{|c|c|c|c|c|c|c|c|c|c|c|c|c|c|c|c|c|c|}
\hline \multirow{2}{*}{\multicolumn{2}{|c|}{$\begin{array}{l}\text { Biofluid } \\
\text { Compound }\end{array}$}} & \multicolumn{4}{|c|}{ Urine } & \multicolumn{4}{|c|}{ Saliva } & \multicolumn{4}{|c|}{ Red blood cells } & \multicolumn{4}{|c|}{ Plasma } \\
\hline & & C & $\mathrm{TC}$ & $\mathrm{F}$ & I & C & $\mathrm{TC}$ & $\mathrm{F}$ & I & C & $\mathrm{TC}$ & $\mathrm{F}$ & $\mathrm{I}$ & C & TC & $\mathrm{F}$ & I \\
\hline \multirow{12}{*}{$\begin{array}{l}\text { Average } \\
\text { concentration } \\
(\mathrm{ppm})\end{array}$} & Week 01 & & & & & & & & & & & & & & & & \\
\hline & Week 02 & & & & & & & & & & & & & & & & \\
\hline & Week 03 & & & & & & & & & & & & & & & & \\
\hline & Week 04 & & & & & & & & & & & & & & & & \\
\hline & Week 05 & & & & & & & & & & & & & & & & \\
\hline & Week 06 & & & & & & & & & & & & & & & & \\
\hline & Week 07 & & & & & & & & & & & & & & & & \\
\hline & Week 08 & & & & & & & & & & & & & & & & \\
\hline & Week 09 & & & & & & & & & & & & & & & & \\
\hline & Week 10 & & & & & & & & & & & & & & & & \\
\hline & Week 11 & & & & & & & & & & & & & & & & \\
\hline & Week 12 & & & & & & & & & & & & & & & & \\
\hline
\end{tabular}

Using the data collected on the amount of lumps and masses developed by the mice, the relative risk for developing lumps when exposed to fenvalerate combustion by-products (at different concentrations) will be established using the following equation:

\section{Equation 1:}

$$
\text { Relative risk }=\frac{(\text { Probability of developing a tumor in a test group) }}{\text { (Probability of developing a tumor in group } 1)}
$$

Using the levels of T4 collected from each group, an analysis using a Kruskal-Wallis test and Dunn's test will be done to verify if the means are statistically different from one another. The first group's data on levels of T4 will also help establish a baseline level of $\mathrm{T} 4$ to monitor hypothyroidism in test groups.

Finally, the data obtained from Kondziela's inverted screen test will also be analyzed using the Kruskal-Wallis test and Dunn's test to check if the means have a significant statistical difference. Results with $\mathrm{p}<0.05$ will be considered statistically significant.

\section{Results}

Based on current literature, the mice exposed to fenvalerate under pyrolytic conditions could present themselves with health conditions related to chronic exposure to combustion by-products, most notably HCN, such as hypothyroidism or iodine deficiency syndromes, amongst other conditions. Since the inhalation of unfiltered smoke can yield augmented concentrations of chemicals in the lungs, and because of the high absorption efficiency of HCN by inhalation, we believe the health effects will be worsened in the mice inhaling the unfiltered 
UNDERGRADUATE RESEARCH IN NATURAL AND CLINICAL SCIENCE AND TECHNOLOGY (URNCST) JOURNAL Read more URNCST Journal articles and submit your own today at: https://www.urncst.com

cannabis smoke containing the combustion by-products. In fact, a dose-response could be expected since there is a dose dependant relationship that exists for acute exposure guideline levels of hydrogen cyanide [10]. Furthermore, the relative risk for developing lumps when exposed to fenvalerate combustion by-products should increase with the concentration, and a significant statistical difference between the means for the control group and test groups should be observable with the collected data. The Kruskal-Wallis and Dunn's tests will allow us to determine which means are different from one another in regards to biomarker levels, as well as the results from Kondziela's inverted screen test [24]. These comparisons will allow us to identify which concentration levels are most important when creating exposure guidelines for fenvalerate.

\section{Discussion}

There is a lack of data on the effects of pesticides when combusted, and effects on consumer health faced with longterm exposure to combustion by-products. Further research will provide information about the health risks associated with chronic exposure to combustion by-products of fenvalerate, specifically HCN. After determining the concentration thresholds for insecticide fumes, alternative and cleaner insecticide options could then be provided for the production of cannabis. In a clinical setting, biofluids could be monitored in a similar way for the detection of hypothyroidism or iodine deficiency syndromes [18,

[23]. However, modifications to the research protocol will have to be made in regards to the method of cannabis consumption of the subjects to properly consider how the Canadian population ingests cannabis.

\section{Conclusion}

The goal of this study is to suggest appropriate regulations for the use of fenvalerate as a pesticide for cannabis depending on the results obtained. Based on the difference of the observed side-effects from the three concentration levels, a more specific limit recommendation could be made. Considering combustion as a factor for pesticide regulation would also enable the construction of a framework for determining adequate pesticides for industrial production of cannabis.

\section{List of Abbreviations}

HCN: hydrogen cyanide

URT: upper respiratory tract

\section{Conflicts of Interest}

All authors declare that they have no conflict of interest.

Ethics Approval and/or Participant Consent

This study did not require ethics approval, as it was a protocol designed for a case competition.

\section{Authors' Contributions}

NL: contributed to study design, drafted the manuscript and gave final approval of the version to be published.

JC: contributed to study design, drafted the manuscript and gave final approval of the version to be published.

RK: contributed to study design, drafted the manuscript and gave final approval of the version to be published.

DES: contributed to study design, created all figures, drafted the manuscript and gave final approval of the version to be published.

\section{Acknowledgements}

We would like to thank the SciNapse Undergraduate Science Case Competition for providing us with the opportunity to tackle an ongoing problem facing the Canadian population. We would also like to thank the SciNapse team for the guidance they provided during the competition.

\section{Funding}

This study was not funded.

\section{References}

[1] CAMH. Cannabis. [cited 2018 Nov 18]. Available from: https://www.camh.ca/-en/health-info/mentalillness-and-addiction-index/cannabis

[2] Government of Canada. Mandatory Cannabis Testing for Pesticide Active Ingredients. [cited 2018 Nov 18] Available from: https://www.canada.ca/en/publichealth/services/publications/drugs-healthproducts/cannabis-testing-pesticide-list-limits.html

[3] Canadian Centre on Substance Use and Addiction. Cannabis. [cited 2018 Nov 18]. Cannabis. Available from: https://www.ccsa.ca/cannabis-canadian-drugsummary

[4] Government of Canada. Canadian Cannabis Survey 2018 Summary. [cited 2018 Nov 20]. Available from: https://www.canada.ca/en/services/health/publications/drugs-health-products/canadian-cannabis-survey-2018summary.html

[5] Government of Canada. Canadian Cannabis Survey 2019 Summary. [cited 2020 Jan 2]. Available from: https://www.canada.ca/en/healthcanada/services/publications/drugs-healthproducts/canadian-cannabis-survey-2019summary.html

[6] Dryburgh L, Bolan NS, Grof CPL, Galettis P, Schneider J, Lucas CJ, Martin JH. Cannabis contaminants: sources, distribution, human toxicity and pharmacologic effects. British Journal of Clinical Pharmacology. 2018 Nov; 84(11):2468-2476. https://doi.org/10.1111/bcp.13695

[7] Lorenz W, Bahadir M, Korte F. Thermolysis of pesticide residues during tobacco smoking. Chemosphere. 1987;16(1):521-522. https://doi.org/10.1016/0045-6535(87)90261-x

[8] Sullivan N, Elzinga S, Raber J. Determination of Pesticide Residues in Cannabis Smoke. Journal of 
UNDERGRADUATE RESEARCH IN NATURAL AND CLINICAL SCIENCE AND TECHNOLOGY (URNCST) JOURNAL Read more URNCST Journal articles and submit your own today at: https://www.urncst.com

Toxicology. 2013;2013(1):1-6. https://doi.org/10.1155/2013/378168

[9] Lewis RJ. Sax's Dangerous Properties of Industrial Materials. Wiley-Interscience. 2004;11(1):1760. https://doi.org/10.1021/ja041002c

[10] Board on Environmental Studies and Toxicology. Acute Exposure Guideline Levels for Selected Airborne Chemicals. The National Academies Press. 2015;19(1):13. https://doi.org/10.17226/21701

[11] Zielinska B, Khlystov A. Current Status of Air Toxics Management and Its Strategies for Controlling Emissions in Taiwan. Toxics. 2016;4(2):8. https://doi.org/10.3390/toxics4020008

[12] Andersen S, Karmisholt J, Pedersen KM, Laurberg P. Reliability of studies of iodine intake and recommendations for number of samples in groups and in individuals. British Journal of Nutrition. 2008;99(4):813-818. https://doi.org/10.1017/S0007114507842292

[13] Agency for Toxic Substances \& Disease Registry. Toxic Substances Portal - Hydrogen Cyanide. [cited 2018 Nov 20] Available from: https://www.atsdr.cdc.gov/MMG/MMG.asp?id=1141\&tid=249

[14] Carson BL, Ellis HV, Herndon BL, Horn EM, Baker LH. Hydrogen Cyanide Health Effects. Office of Mobile Source Air pollution Control; 1981 Sep 11.

[15] National Research Concil (US) Subcommittee on Acute Exposure Guideline Levels. Acute Exposure Guideline Levels for Selected Airborne Chemicals: Volume 2. [cited 2018 Nov 20] Available from: https://www.ncbi.nlm.nih.gov/books/NBK207601/

[16] Johnson, M. Laboratory Mice and Rats. Materials and Methods. 2012; 2:113.
[17] Ypsilantis P, Politou M, Anagnostopoulos C, Kortsaris A, Simopoulos C. A Rat Model of Cigarette Smoke Abuse Liability. Comparative Medicine. 2012; 62(5):395-399.

[18] Vinnakota CV, Peetha NS, Perrizo MG, Ferris DG, Oda RP, Rockwood GA, Logue BA. Comparison of cyanide exposure markers in the biofluids of smokers and non-smokers. Biomarkers. 2012; 17(7):625-633. https://doi.org/10.3109/1354750X.2012.709880

[19] Fire Engineering. Cyanide Poisoning: How Much of a Threat. [cited 2018 Nov 20] Available from: https://www.fireengineering.com/firefighting/ knapp.html

[20] Burkholder T, Foltz C, Karlsson E, Linton G, Smith J. Health Evaluation of Experimental Laboratory Mice. Current Protocols. 2012; 2012(1):145-165. https://doi.org/10.1002/9780470942390.mo110217

[21] Thorson L. Thyroid Diseases in Rodent Species. Veterinary Clinics of North America: Exotic Animal Practice. 2014; 17(1):51-67. https://doi.org/10.1016/j.cvex.2013.09.002

[22] Deacon R. Measuring the Strength of Mice. Journal of Visualized Experiments. 2013; 76(1):4. https://doi.org/10.3791/2610

[23] Razvi, Salman \& Mrabeti, Sanaa. Challenges in Interpreting Thyroid Stimulating Hormone Results in the Diagnosis of Thyroid Dysfunction. Journal of Thyroid Research. 2019. https://doi.org/10.1155/2019/4106816

[24] Dinno, A. Nonparametric Pairwise Multiple Comparisons in Independent Groups using Dunn's Test. The Stata Journal, 15(1), 292-300. https://doi.org/10.1177/1536867X1501500117 
UNDERGRADUATE RESEARCH IN NATURAL AND CLINICAL SCIENCE AND TECHNOLOGY (URNCST) JOURNAL Read more URNCST Journal articles and submit your own today at: https://www.urncst.com

\section{Article Information}

Managing Editor: Jeremy Y. Ng

Peer Reviewers: Jennifer Williams, Vinita Dhir

Article Dates: Received Nov 18 19; Accepted Jan 17 20; Published Feb 0720

\section{Citation}

Laflamme N, Candeliere J, Krnel R, Stamatakos DE. Effects of the inhalation of fenvalerate combustion products on the respiratory, digestive, endocrine, and muscular systems of mice: A research protocol. URNCST Journal. 2020 Feb 07: 4(2). https://urncst.com/index.php/urncst/article/view/172

DOI Link: https://doi.org/10.26685/urncst.172

\section{Copyright}

(C) Nicholas Laflamme, Jasmine Candeliere, Rebecca Krnel. Darius E. Stamatakos (2020). Published first in the Undergraduate Research in Natural and Clinical Science and Technology (URNCST) Journal. This is an open access article distributed under the terms of the Creative Commons Attribution License (https://creativecommons.org/licenses/by/4.0/), which permits unrestricted use, distribution, and reproduction in any medium, provided the original work, first published in the Undergraduate Research in Natural and Clinical Science and Technology (URNCST) Journal, is properly cited. The complete bibliographic information, a link to the original publication on http://www.urncst.com, as well as this copyright and license information must be included.

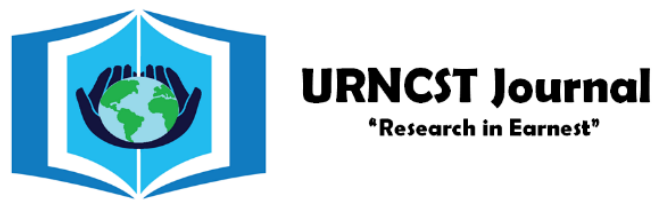
Funded by the Government of Canada

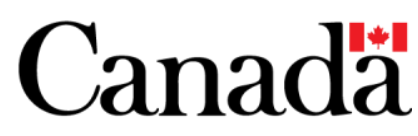

Do you research in earnest? Submit your next undergraduate research article to the URNCST Journal!

| Open Access | Peer-Reviewed | Rapid Turnaround Time | International | | Broad and Multidisciplinary | Indexed | Innovative | Social Media Promoted |

Pre-submission inquiries? Send us an email at info@ urncst.com | Facebook, Twitter and LinkedIn: @URNCST

Submit YOUR manuscript today at https://www.urncst.com! 